\title{
The Embodied Deaf God: A God Just Like Us
}

By Wayne Morris

Wayne Morris is Professor of Contextual Theology and Deputy Dean of the Faculty of Arts and Humanities at the University of Chester, UK. He is a former editor of the journal Practical Theology, and is the author of (with Roy MCloughry) Making a World of Difference: Christian Reflections on Disability (2002), Theology without Words: Theology in the Deaf Community (2008), and Salvation as Praxis: A Practical Theology of Salvation for a MultiFaith World (2014).

\section{Abstract}

The body, whether understood positively or negatively, has always been a part of Christian thinking and practice. However, the body has often been viewed as a 'prison' from which humans should seek to escape. In this paper, I suggest that, despite dominant theological discourses that have sought to negate the human body - and especially bodies that do not conform to certain norms - we find in the Christian tradition extraordinary theologies and spiritualities of survival and resistance expressed through the body. Deaf perspectives on God provide one example of this. By giving attention to the ways in which Deaf people imagine God as embodied, I argue that we can imagine ourselves as just like God concretely in God's image in our embodied condition, and that in this discovery, we can learn to affirm our embodied states in all their diversity.

\section{Key Words:}

Embodied Theology, Deaf Theology, Survival, Resistance, Spirituality 


\section{Introduction}

The human body, and its place in the Christian tradition, has been the focus of much reflection and analysis by contextual theologians from a variety of perspectives in recent decades. Isherwood and Stuart locate the origins of this focus on the body in the experiences of 'women and gay men' who 'came to understand that the way society viewed their bodies was the site of their oppression' ${ }^{1}$ Certainly a number of feminist and queer perspectives in body theology have been developed that critique both theological and social perspectives and practices towards the body. In turn, many have then sought to construct alternative theologies, that affirm embodied existence, show how the body can be a site of spiritual expression and, indeed, it has been argued that God is also embodied. ${ }^{2}$ This collection of essays and reflections constitutes a very important addition to thinking about body theologies and, in particular, the various ways in which the body can be a site of lived spiritual expression and experience.

When I was asked to make a contribution to this collection, I was asked to do so as a respondent to the rest of the papers. In considering the contributions I have read, I reflected that much my academic work has been focussed predominantly on theologies relating to disabled people and Deaf people and that the many discourses that fall under these headings themselves represent body theologies, theologies that have emerged from people

\footnotetext{
${ }^{1}$ L. Isherwood and E. Stuart, Introducing Body Theology, p.20.

${ }^{2}$ See, for example: M. Althaus-Reid and L. Isherwood (eds), Controversies in Body Theology (London: SMC Press, 2008); G. Loughlin (ed.), Queer Theology: Rethinking the Western Body (Oxford: Blackwell, 2007); J. B. Nelson, Body Theology (Louisville: Westminster/John Knox Press, 1992).
} 
whose bodies have been the sites of their oppression. In the many contributions made to body theology by people with disabilities and people who are Deaf, not only do they propose new ways of thinking about disabled and Deaf bodies, they have also challenged the ways in which dominant discourses about God that have often rendered God invisible and disembodied. I would like to contribute to this collection, which focuses on lived human spiritual expression, by suggesting that God's spiritual practices can also be understood as embodied practices. Thus, when human beings experience something of the divine through running, the martial arts, swimming, sports more broadly, ministerial practices with disabled people or in inner cities, pilgrimages, music, and dance, they do so in communion with a God whose own practices of engagement with us are also embodied; and I will make this suggestion with particular attention to Deaf theologies.

First, however, I would like to explore why we need to pay greater attention to the body in Christian theology and to suggest that, while human bodies have often been repressed or marginalized in and by much Christian discourse, they have always been a part of Christian self-understanding and practice, whether viewed positively or negatively.

\section{The Body as a Prison in Christian Theology}

Much literature on the body, from feminist and queer perspectives, argues that the way the body has predominantly been viewed has been as that part of the human self that all human persons should denigrate, abuse and from which they should seek escape. Such a view of the body is heightened when that body does not conform to a white, male, heterosexual, able-bodied norm. Dominant soteriological discourses provide one example of the way such perspectives on the body have been expressed and the reasons given for such 
a negative view of the body. Rosemary Radford Ruether argues that the dominant view on redemption has been one in which 'our human nature is seen as having become totally severed due to $\sin ^{\prime}$ and that humans should therefore reject their bodies in favour of 'a heavenly world that is to be our true home after death'. ${ }^{3}$ The body is, therefore, usually understood as not a full part of the true human self, but it is rather viewed as a 'prison' from which our true selves should seek to escape, a possibility that will be realized only in some form of future eschatological existence (notwithstanding the contradiction of the notion of a bodily resurrection).

In the Gospel of Matthew, Jesus chastises the disciples for sleeping in Gethsemane just before he is arrested, saying, 'Stay awake and pray that you may not come into the time of trial; the spirit is willing, but the flesh is weak' (Matthew 26.41). It is this dualism between body (or more precisely here, 'flesh') and spirit of which Ruether is perhaps speaking, which begins to explain why the body is often viewed so negatively; the body is thought to not only imprison our spirits, but our materiality over spirituality represents that part of us which is prone to sin or weakness. Such views have often led to the abuse or neglect of the body such as, for example, in medieval practices of flagellation or even starvation of the body as physical expressions of religious devotion; acts that led to considerable physical suffering, in particular, but not exclusively, among women. ${ }^{4}$

${ }^{3}$ R. R. Ruether, Introducing Redemption in Christian Feminism (Sheffield: Sheffield Academic Press, 1998), p. 63.

${ }^{4}$ R. M. Bell, Holy Anorexia (Chicago: University of Chicago Press, 1987) discusses the way that certain medieval ascetic practices of devotion would today be understood as the life threatening condition of Anorexia and other related conditions. 
It is not only the body and the spirit that theologies of salvation have set up in opposition to each other, but also the body and mind. It is a widely held and asserted discourse in many Christian traditions that human beings are made in the image of God. This idea of imago dei has been used not only as a way of speaking of the distinctiveness of humans from other animals and other parts of creation, but also articulates one of the ways in which Christian theology has defended the primacy of humans in creation. However, in both Western and Eastern traditions, that which has been thought to be the imago dei in humans, it has been argued, is the human capacity to reason or to think. ${ }^{5}$ If that which makes humans in God's image is their capacity to reason then one can grow more into the likeness of God, or 'imitate Christ', through the intellect. If humans are to become 'like God' in another possible world in the future, then that part of human being that becomes most like God and is therefore most worthy of salvation, is the image that is already in us; that is, our minds. The human task is understood in this approach, therefore, as that the true self, in this case the mind, should seek to transcend the body, as it is our bodies that make us most unlike God (a notion I will contest shortly). So the mind and spirit get humans closer to God, while the body is a prison that separates humans from God. That being so, it is no wonder that embodied existence has often been viewed so negatively. What we see in more contemporary theologies of the body, especially from the perspectives of those whose bodies have been the sites of their oppression, are discourses of resistance to the types of traditions I have outlined with a view to not only affirming embodied existence, but that a

\footnotetext{
${ }^{5}$. See a discussion of this in F. Kerr, Twentieth Century Catholic Theologians (Oxford: Blackwell, 2007) pp.19396. Kerr, however, notes a shift in thinking in the twentieth century in Catholic thought whereby the imago dei is, equally problematically, found in gender complementarity expressed especially in heterosexual marriage.
} 
diversity of bodies that do not conform to white, able-bodied, heterosexual, male norms, are a part of the good and wonderful creation of a God who embraces this diversity within God's own body.

\section{The Body in History as a Site of Resistance}

I would like to further suggest that 'extra-ordinary' body theologies have always been a part of Christian spiritual practice, that have often included embodied discourses and practices of resistance to oppression. In 2002, Jeff Astley developed the notion of 'ordinary theology' that he defined as 'the theology and theologizing of Christians who have received little or no theological education of a scholarly, academic or systematic kind'. ${ }^{6}$ In contrast, Louise Lawrence prefers the term 'folk' instead of 'ordinary' in her studies on contextual Bible study groups so as 'to demonstrate and celebrate the community consciousness and experience of those interpreters' ${ }^{7}$ Lawrence is right to reject the pejorative term 'ordinary', which does not do justice to the often extra-ordinary and complex systems and beliefs that can be found outside of the official written documents of church authorities and academic theologians. Indeed, she notes that in Gerald West's later work, he shifts from talking about 'ordinary' to 'extra-ordinary' perspectives in his contextual Bible studies. ${ }^{8}$ As I will suggest shortly, many theologies of Deafness and disability have turned to the Incarnation as a way of showing that God affirms embodied existence. Thus, a positive perspective on the body in

\footnotetext{
6 J. Astley, Ordinary Theology: Looking, Listening and Learning in Theology (Aldershot: Ashgate, 2002) p.56 (italics retained from the original quotation).

${ }^{7}$ L. J. Lawrence, The Word in Place: Reading the New Testament in Contemporary Contexts (London: SPCK, 2009) p.23.

${ }^{8}$ L. J. Lawrence, The Word in Place, p.23.
} 
Christian history is rooted in the very origins of the Christian tradition itself whereby, in the person of Jesus, God 'became flesh' (John 1.14). This radical revelation of God was perhaps the beginning of an embodied theology of resistance to those who exercised power over the formal ways in which it was considered to be acceptable to speak and think about God.

Another aspect of my work has, in recent years, been focussed on developing an understanding of a particularly Welsh theology. This has, to a large extent, been a personal quest in trying to understand the distinctive theological discourses of the nation with which I identify and of which I am a part. Wales, perhaps like Australia and Aotearoa New Zealand, is a land that was colonized by a much stronger and bigger power several centuries ago, followed by repeated attempts to suppress the languages, cultures and traditions of the indigenous populations. ${ }^{9}$ That is, the oppression of the very ways in which our bodies express who we are. To my mind, part of the Welsh resistance to such oppression and the survival of our language, culture and traditions, was through embodied spiritualities extraordinary theologies of resistance. Most notably, the Welsh chapels were among the few sites in which Welsh people could be free to use their language, articulate their poetry, and sing their music as embodied expressions of their identities; traditions maintained today through eisteddfodau. ${ }^{10}$ Chapels themselves represented a concrete symbol of

\footnotetext{
${ }^{9}$ See discussion in R. O. Jones, 'The Welsh Language in Patagonia', in G. H. Jenkins (ed.), Language and Community in the Nineteenth Century (Cardiff, 1998) pp. 287-316. Here Jones explains how the search for a new homeland for Wales in the nineteenth century was driven by a desire to escape this kind of oppressions.

${ }^{10}$ H. T. Edwards, The Eisteddfod (Cardiff, 2016), p.5 explains that 'eisteddfod' literally means 'sitting together'. They are cultural festivals and competitions that celebrate Welsh music, poetry, drama, and literature.
} 
resistance to colonialism and the power of the Church of England in Wales. ${ }^{11}$ Further, there is a very strong sense in Wales in which human persons and the land are interconnected with one another. Perhaps this is because the land, with its mountainous terrains, was largely responsible for protecting Welsh people from anglification. In turn, this has led to an honouring of the land and a sense in which it is understood as sacred. We do not find this in formal written theologies, but in concrete, embodied theologies expressed in song and poetry, through dance, and in our naming of places with sacred names so that as our bodies move around our land, we are reminded that everything around is sacred..$^{12}$ In our anthem, we commit ourselves to and honour the land no less than seven times in as many lines, and you cannot travel in Wales for more than a few miles without entering a town or village that begins with 'Llan..' indicating that that place is sacred.

I make these points about Wales because I think it suggests that among marginalized and oppressed groups, when written formal theological discourses of resistance were too dangerous to produce, then concrete, physical embodied expressions of resistance from extraordinary people were developed. I also raise this as a part of my response here because, I hope, it might open up the possibility of further conversation and exploration with colleagues from Australia and Aotearoa New Zealand with regard to voices that are sadly largely absent in this collection. It was striking to me that with so many contributions

\footnotetext{
${ }^{11}$ R. O. Jones, 'The Welsh Language in Patagonia', pp. 292-3

${ }^{12}$ It is interesting to note, that following the industrial revolution in the $19^{\text {th }}$ century, many Welsh place names were 'anglicised' perhaps as an attempt to change the place and the land that had been sacred to Welsh people for so many centuries. Welsh speaking communities rarely adopted the English names for their towns and villages.
} 
from Australia and one from Aotearoa New Zealand, that we do not get much sense of the embodied spiritual practices of indigenous peoples who have inhabited those lands for centuries. Perhaps, as with many embodied practices of other extra-ordinary but marginalized peoples, such practices are not written and recorded for wider consumption. I do not presume to know or to be able to comment on the extent to which anything I have said about Wales parallels with the practiced spiritualities of indigenous peoples in Australia and Aotearoa, but perhaps a future development on reflections on embodied spiritual practices from these lands could include more voices from Indigenous peoples, giving attention to the extent to which such practices reflect discourses of resistance and survival as well as the connectedness of the human body with the land they inhabit and of which they are a part.

Having argued that the body - for good and bad - has been a part of Christian spiritual practices since the beginning of the Jesus movement, I would now like to turn back to Deaf perspectives on the body in order to suggest that just as human beings engage in embodied spiritual practices, so as God engages with human beings, God can be understood and experienced as an embodied God.

\section{The Deaf Embodied God}

As with feminist and queer theologies, Deaf and disabled theologies have sought to deconstruct historic and established theologies of the body that have served as tools of marginalization and oppression. These are also theologies of resistance and survival. Consider, for example, the possibility of disabled people's salvation. If, as it has been proposed, the body has been viewed as a prison and therefore lacks redemptive qualities, 
and the mind is the imago dei in us, it has historically been concluded that there is reduced soteriological hope if one's mind does not exhibit the capacity to think or reason according to established conventions, due to mental illness, profound learning disability or dementiarelated conditions. ${ }^{13}$ Not only do such views of the mind over the body serve to dehumanize some members of our societies, but they also justify the privileged position of those who have the capacity to think and reason according to established conventions of rational thought and argument.

If bodies in general have often been viewed negatively, as I have suggested, then bodies that are considered to be in some way not 'functioning properly', such as Deaf and disabled bodies, have been viewed as being even more problematic. This is exemplified in the way the healing narratives in the Gospels are often interpreted in historic and established theologies and practices of 'healing'. At the beginning of Jesus' ministry, early in Luke's Gospel, he declares that one of the signs of the kingdom will be the 'restoration of sight to the blind' (Luke 4.18). In this vein, there are numerous Gospel narratives of Jesus encountering people who today would be called Deaf or disabled, whose bodies are changed so as to conform to established norms. ${ }^{14}$ Indeed, in Mark 7.31-37, there is a story of a Deaf man for whom this is true. The disabled condition is invariably associated with sin in such narratives (for example, Luke 5.20 and Matthew 9.5) and the changed body a sign of

\footnotetext{
${ }^{13}$ See discussion in, W. Morris, 'Transforming Tyrannies: Disability and Christian Theologies of Salvation' In H. Bacon and W. Morris with S. Knowles (eds), Transforming Exclusion: Engaging Faith Perspectives (London, T\&T Clark, 2011). pp. 121-134.

${ }^{14}$ For a discussion of a number of such narratives, see, K. Black, A Healing Homiletic: Preaching and Disability (Nashville: Abingdon Press, 1996).
} 
repentance and of an appropriate level of faith (for example, Mark 11.52 and Luke 8.48). If there is such a thing as a resurrected body in the future saved condition of the human, in these New Testament narratives at least, it appears as though the Deaf or disabled body will not be resurrected as it is. Rather, it will be changed, and that has been widely interpreted to mean 'normalized' or made 'able-bodied'.

In response to such perspectives, many Deaf and disabled theologies have turned to Christology and, in particular, the incarnation. Eiesland's landmark text, The Disabled God, argued that in the resurrected body of Christ, the wounds of the cross remained in his body through into his ascension into heaven. Through the cross, Jesus' body was 'broken' and, as Jesus was 'God made flesh' so God identified with the lives of disabled people whose bodies might also be described as 'broken' or 'wounded'. This, she argues, provides a liberatory framework through which disabled people can view their own bodies and lives in the church and society. God, in the incarnate Christ of the resurrection is disabled and identifies with disabled experience. ${ }^{15}$ Amanda Shao Tan, ${ }^{16}$ Randall Otto ${ }^{17}$ Roy McCloughry with Wayne Morris, ${ }^{18}$ and John Hull ${ }^{19}$ have each in turn developed theologies of a disabled God which

${ }^{15}$ See this argument that constitutes her book: N. L. Eiesland, The Disabled God: Toward A Liberatory Theology of Disability (Nashville: Abingdon, 1994).

${ }^{16}$ A. S. Tan, 'The Disabled Christ', in Transformation: An International Evangelical Dialogue on Mission and Ethics, 1998, 15(4) pp.8-14.

${ }^{17}$ R. Otto, 'Incarnated or Incapacitated? Another Look at 'The Disabled Christ', in Phronésis, 1997, 4(1) pp.6575.

${ }^{18}$ R. McCloughry and W. Morris, Making a World of Difference: Christian Reflections on Disability. (London: SPCK, 2002) pp.64-73.

19 J. M. Hull, In the Beginning there was Darkness (London: SCM Press, 2001) pp.127-48. 
focus in some way or other on Christology noting that, through the limitations of the incarnation itself, or the limitations imposed on Jesus during his earthly life, God experiences disability. Because in these discourses on the disabled God, disability is referring principally to physical or sensory impairments, and disability is defined according to bodily characteristics, the incarnate and now ascended body of God can be described as disabled.

Mary Weir, ${ }^{20}$ Hannah Lewis ${ }^{21}$ and Wayne Morris ${ }^{22}$ represent the main views that have been developed in thinking about the possibility of a particularly Deaf God and, as with disability perspectives, have focussed on the incarnation. The incarnation, they variously argue, is necessary in Deaf theology as the disembodied faceless God of the Old Testament is, as Weir argues, made visible and touchable and therefore accessible to 'Deaf sensibilities' in Christ. ${ }^{23}$ If God is accessible to Deaf people in the incarnation and thus able to relate to Deaf people, then God, in Jesus, is Deaf inasmuch as God can engage with and identify with Deaf experience and culture, exemplified to a large degree in the encounter with the Deaf man in Mark's gospel. As with disability theologies, these Deaf theologies find an affirmation for a Deaf existence and way of living in a visible, touchable, incarnate God.

\footnotetext{
${ }^{20}$ M. K. Weir, 'Made Deaf in God's Image', in International Ecumenical Working Group (eds.), The Place of Deaf People in the Church (Northampton: Visible Communications, 1996) pp.1-10.

${ }^{21}$ H. Lewis, Deaf Liberation Theology (Aldershot: Ashgate, 2007) pp. 149-53. Here Lewis develops the notion of Jesus as a 'Deaf Liberator'.

${ }^{22}$ W. Morris, Theology without Words: Theology in the Deaf Community. (Aldershot: Ashgate, 2008) pp.137-56.

${ }^{23}$ M. K. Weir, 'Made Deaf in God's Image', p.9.
} 
One Deaf person in fieldwork I have conducted with Deaf people described the way that she perceived that most hearing Christians speak about human-divine interaction as being disembodied. It resembled two people communicating with each other from separate rooms, she explained. The communication is principally oral/aural (the main metaphors used for human-divine communication in Christianity certainly reflect that, even if that is not literally what happens) and one being able to see or touch the other is unnecessary. God is thus understood to exist far off as some bodiless reality that humans engage with when God speaks to humans and humans to God. Such a God, however, did not reflect the way that she or many other Deaf people imagined God. Deaf people can only communicate fully with someone in their first or preferred language, in this instance British Sign Language, when they have a physical presence before them and when they can see the other, face to face. As so many Deaf people struggle with written communication and there are no current written forms of British Sign Language in use, there really is no substitute for embodied communication.

Deaf people need to be able to see, to express using the hands, the face and the space around the body, and because they rely so much on physical reality to relate, they use touch too. Given the main ways in which the body has been understood in Christianity, and especially Deaf and disabled bodies, we would be forgiven for thinking either that Deaf people would not even entertain the possibility of a Christian faith as Deaf people or that, even if they did, God would not be interested unless they first became hearing. What is remarkable is that despite those theologies that suggest a Deaf person cannot be fully human and cannot be saved in their Deaf condition, many Deaf people nevertheless do have a faith and participate in a faith community. But instead of accepting the established 
conventions and orthodoxies about the body, the disabled body, and divine-human interaction, they have constructed alternative theologies of resistance and survival that reflect their particular culture: Christianity according to the Deaf-way!

Unlike many alternative body theologies that turn to notions of incarnation, Deaf people, I suggest, in my fieldwork I discovered that in the Deaf community, the whole of God is understood to be an embodied reality. That is, that there is an understanding in Deaf theology that God is embodied, not simply in becoming flesh in the incarnation, but at all times and in all places; the whole of God, however understood, is a God who is embodied. I would like to explain this Deaf imagining of an embodied God by drawing on two further ways in which Deaf people imagine and embodied God through the way that they engage in prayer, one at the personal level and the second observed in a congregational context.

In Theology Without Words, in seeking to articulate the various ways through which Deaf people relate to God, it was explained:

Deaf people have claimed that they are able to feel something of God with them in a physical way, often in the context of private prayer. This... reveals a God who is close to and involved with creation... This also suggests again that God is able to relate to Deaf people, this time not through the visual but entirely through touch ${ }^{24}$.

Commenting on this experience of Deaf people later on, I explained that,

${ }^{24}$ W. Morris, Theology without Words, p.88. 
Scientists and psychologists would no doubt be interested in Deaf people's experiences and I have gathered no objective proof (if that were possible) to support what they have said about God touching them. Such experiences may indeed be interesting psychological phenomena, but also they point again to a view of God who understands Deaf culture and makes use of that to reveal God's self to Deaf people ${ }^{25}$.

What is most significant for our purposes here is a Deaf imagining and understanding of a God who engages with Deaf people physically through some form of embodied encounter. This suggests not only that the Deaf person's body is essential in relating to God, but that God must also be physically embodied in some form if God is to be felt in this kind of way. This understanding of an encounter with God in prayer was never interpreted as a purely Christological encounter but an interaction with the whole of God's being.

A second example of an understanding of an embodied God can also be found in the way Deaf people engaged in prayer in a corporate context. In Anglican liturgies in my own tradition, for example, it is customary to begin prayers in church with the words 'let us pray' and to use phrases that invite God to 'hear' the prayers of the people. ${ }^{26}$ In the Deaf church, at the moment of corporate prayer, once the leader had everyone's attention at the point the prayers began, the leader began by looking up towards God (God is always located

\footnotetext{
${ }^{25}$ W. Morris, Theology without Words, p.153.

${ }^{26}$ See, for example, Church of England, Common Worship: Services and Prayers of the Church of England (London: Church House Publishing, 2000) p.174.
} 
physically somewhere... usually in a place located above the person signing - in 'heaven'). God must be somewhere and embodied and not everywhere and mere 'spirit' or nowhere, for God, in Deaf theology, is always embodied. Next, the leader lifts up their hand and makes a tapping motion in the air, just as a Deaf person would tap someone on the shoulder to get their attention. The leader then takes on the role of God and signs so as to suggest that God has turned around to give the congregation full attention and focuses on their prayers. Because God is embodied, God must turn around to look, for God cannot see out of the back of God's head. The prayers are then signed up towards God. God, therefore, is embodied and responds to touch (not sound) and engages with people not through aural/oral communication, but through embodied communication.

In Deaf theology, these examples of Deaf practices of prayer suggest a Deaf perspective on God as a reality that is entirely embodied. A body theology that re-imagines established notions of God and the human body in the Deaf community is located not simply in notions of the incarnation, but is located in the fullness of God's being and in how God engages with embodied humans. Anything less than a fully embodied God seemed meaningless in the Deaf community. God lives with the embodied limitations of being Deaf and, as a result, in relating to Deaf people, must turn around if God is to engage with the Deaf person in any meaningful way; communication can only take place face to face. God is thus neither superhuman in terms of sensory, physical or intellectual capacities, but just like the Deaf person. God no longer reflects the image of the historic able-bodied, heterosexual, male norm. Instead, Deafness is affirmed as a way of existing in the world without the need to conform to such norms. The God of the Deaf community is thus nothing less than an embodied God who relates to Deaf people in an embodied way. 


\section{Conclusion}

A series of interventions, such as those contained in this collection, helps us to take conversations forward in ways that have not been considered before, while also revealing spaces in which new research could be pursued. My proposal here is that just as human beings experience and encounter God as embodied persons, so we learn from the spiritual practices of Deaf people, that in God's interactions and encounters with human beings, God can also be imagined as embodied. Thus, in our embodied states, in all their diversity, we image the embodied God. I have also suggested that many theologies that have given attention to the body in recent decades have done so from experiences of oppression and that, perhaps, theologies and spiritualities expressed through the body have always been a part of discourses of survival and resistance among marginalized and oppressed peoples. I have given one example of where this is the case but there are, no doubt, many others. As we note those spaces in which there is opportunity for further research that might deepen our understanding of God and humanity, a next step, perhaps, for scholars from where many of these important contributions have come, would be to consider those theologies and spiritualities of resistance and survival in those lands from among those whose voices are largely absent. Nevertheless, it has been a great privilege to be able to contribute to this important collection of essays and reflections that extend our understanding of embodied spiritual practices and experiences so much.

\section{Bibliography}

Althaus-Reid, M. and L. Isherwood, (eds.), Controversies in Body Theology (London: SCM Press, 2008). 
Astley, J., Ordinary Theology: Looking, Listening and Learning in Theology (Aldershot: Ashgate, 2002).

Bell, R. M. Holy Anorexia (Chicago: University of Chicago Press, 1987).

Black, K., A Healing Homiletic: Preaching and Disability (Nashville: Abingdon Press, 1996).

Church of England, Common Worship: Services and Prayers of the Church of England (London: Church House Publishing, 2000).

Edwards, H. T. The Eisteddfod (Cardiff: University of Wales Press, 2016),

Eiesland, N., The Disabled God: Towards a Liberatory Theology of Disability (Nashville: Abingdon, 1994).

Hull. J. M., In the Beginning there was Darkness (London: SCM Press, 2001).

Isherwood, L. \& E. Stuart, Introducing Body Theology (Sheffield: Sheffield Academic Press, 1998).

Kerr, F., Twentieth Century Catholic Theologians: From Neoscholasticism to Nuptial Mysticism (Oxford: Blackwell, 2007)

Jones, R. O., 'The Welsh Language in Patagonia', in G. H. Jenkins (ed.), Language and Community in the Nineteenth Century (Cardiff, 1998) pp. 287-316.

Lawrence, L. J., The Word in Place: Reading the New Testament in Contemporary Contexts (London: SPCK, 2009).

Lewis, H., Deaf Liberation Theology (Aldershot: Ashgate, 2007).

Loughlin, G., (ed.), Queer Theology: Rethinking the Western Body (Oxford: Blackwell, 2007).

McClouughry, R. and W. Morris, Making a World of Difference: Christian Reflections on Disability (London: SPCK. 2002).

Morris, W., Theology Without Words: Theology in the Deaf Community (Aldershot: Ashgate, 2008). 
W. Morris, 'Transforming Tyrannies: Disability and Christian Theologies of Salvation' In H. Bacon and W. Morris with S. Knowles (eds), Transforming Exclusion: Engaging Faith Perspectives (London, T\&T Clark, 2011). pp. 121-134.

Nelson, J. B., Body Theology (Louisville: Westminster/John Knox Press, 1992).

Otto, R., 'Incarnated or Incapacitated? Another Look at 'The Disabled Christ', in Phronésis, 1997, 4(1) pp.65-75.

Ruether, R. R., Introducing Redemption in Christian Feminism (Sheffield: Sheffield Academic Press, 1998).

Tan, A. S., 'The Disabled Christ', in Transformation: An International Evangelical Dialogue on Mission and Ethics, 1998, 15(4) pp.8-14.

Weir, M. K. 'Made Deaf in God's Image', in International Ecumenical Working Group (eds.), The Place of Deaf People in the Church (Northampton: Visible Communications, 1996) pp.110. 